\title{
Evaluation of the Potential of Raman Microspectroscopy for Prediction of Chemotherapeutic Response to Cisplatin in Lung Adenocarcinoma
}

\author{
Haq Nawaz \\ Technological University Dublin, haq.nawaz@tudublin.ie \\ Franck Bonnier \\ Technological University Dublin, Franck.Bonnier@tudublin.ie \\ Peter Knief \\ Technological University Dublin, peter.knief@tudublin.ie

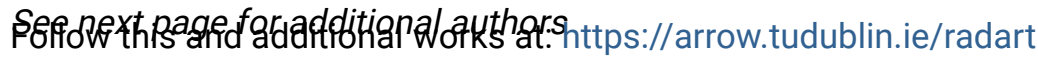 \\ Part of the Biological and Chemical Physics Commons
}

\section{Recommended Citation}

Nawaz, H. et al (2010) Evaluation of the potential of Raman microspectroscopy for prediction of chemotherapeutic response to cisplatin in lung adenocarcinoma. Analyst,vol. 135, no.12 pp.3070-6. doi:10.1039/c0an00541j

This Article is brought to you for free and open access by the Radiation and Environmental Science Centre at ARROW@TU Dublin. It has been accepted for inclusion in Articles by an authorized administrator of ARROW@TU Dublin. For more information, please contact arrow.admin@tudublin.ie, aisling.coyne@tudublin.ie, gerard.connolly@tudublin.ie.

Funder: Technology Sector Research (Strand III) programme of the Irish Higher Education Authority and the Irish HEA Programme for Research in Third Level Institutions, Cycle 4 National Biophotonics and Imaging Platform for Ireland (NBIPI).

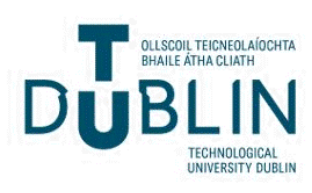




\section{Authors}

Haq Nawaz, Franck Bonnier, Peter Knief, Orla Howe, Fiona Lyng, Aidan Meade, and Hugh Byrne

This article is available at ARROW@TU Dublin: https://arrow.tudublin.ie/radart/15 


\title{
Evaluation of the potential of Raman Microspectroscopy for prediction of chemotherapeutic response to cisplatin in lung adenocarcinoma
}

\author{
Haq Nawaz $^{\mathrm{a} *}$, Franck Bonnier ${ }^{\mathrm{b}}$, Peter Knief ${ }^{\mathrm{b}}$, Orla Howe, ${ }^{\mathrm{a}, \mathrm{c}}$, Hugh J. Byrne ${ }^{\mathrm{b}}$, Fiona M. Lyng ${ }^{\mathrm{a} *}$, Aidan D. \\ Meade $^{\mathrm{a}, \mathrm{b}}$ \\ a. DIT Centre for Radiation and Environmental Science (RESC), Focas Research Institute, Dublin Institute of Technology, Kevin Street, \\ Dublin 8, Ireland \\ b. Focas Research Institute, Dublin Institute of Technology, Kevin Street, Dublin 8, Ireland \\ C. School of Biological Sciences, Dublin Institute of Technology, Kevin Street, Dublin 8, Ireland \\ 10 * Corresponding Author: Haq Nawaz, Radiation and Environmental Science Centre (RESC), Focas Research Institute, Dublin Institute of \\ Technology, Kevin Street, Dublin 8, Ireland, haq.nawaz@dit.ie
}

\author{
Received (in $X X X, X X X)$ Xth $X X X X X X X X X 200 X$, Accepted Xth $X X X X X X X X X 200 X$ \\ First published on the web $X$ th $X X X X X X X X X 200 X$ \\ is DOI: 10.1039/b000000x
}

\begin{abstract}
The study of the interaction of anticancer drugs with mammalian cells in vitro is important to elucidate the mechanisms of action of the drug on its biological targets. In this context, Raman spectroscopy is a potential candidate for high throughput, noninvasive analysis. To 20 explore this potential, the interaction of cis-Diamminedichloroplatinum (II) (Cisplatin) with a human lung adenocarcinoma cell line (A549) was investigated using Raman microspectroscopy. The results were correlated with parallel measurements from the MTT cytotoxicity assay, which yielded an $\mathrm{IC}_{50}$ value of $1.2 \pm 0.2 \mu \mathrm{M}$. To further confirm the spectral results, Raman spectra were also acquired from DNA extracted from A549 cells exposed to cisplatin and from unexposed controls. Partial least squares (PLS) multivariate regression and PLS Jack-knifing were employed to highlight spectral regions which varied in a statistically significant manner with ${ }_{25}$ exposure to cisplatin and with the resultant changes in cellular physiology measured by the MTT assay. The results demonstrate the potential of the cellular Raman spectrum to non-invasively elucidate spectral changes that have their origin either in the biochemical interaction of external agents with the cell or its physiological response, allowing the prediction of the cellular response and the identification of the origin of the chemotherapeutic response at a molecular level in the cell.
\end{abstract}

\section{${ }_{30}$ Introduction}

For the design of new anticancer drugs, an in-depth understanding of the mechanisms underlying their biological effects is required. It is therefore of interest to 35 understand details of the molecular and biochemical mechanisms associated with the biological activity of existing commercial anti-cancer agents. The potential of confocal Raman microspectroscopy (CRM) for the analysis of biological tissue ${ }^{1}$ and the effect of external 40 agents on the cell ${ }^{2-6}$ has been demonstrated. CRM is noninvasive, cost effective, rapid and requires no sample labelling prior to analysis ${ }^{7}$. The technique, with its counterpart Fourier transform infrared microspectroscopy, has great potential to explore sub-cellular biochemical ${ }_{45}$ structure as exemplified by its use in studies investigating the action of various agents on biological macromolecules as well as their interaction with cancer cells ${ }^{7-13}$.

Validation of CRM in the quantitative measurement of the ${ }_{50}$ biochemical and physiological effects of known chemotherapeutic agents is required before it may be used for studies of novel chemical treatments. Cisplatin (cisDiamminedichloroplatinum (II)) is a well established chemotherapeutic agent with a known mode of action. In ${ }_{55}$ the nucleus, it binds with DNA forming inter-strand and intra-strand crosslinks which lead to cell cycle arrest and ${ }_{60}$ apoptosis $^{14}$. The formation of inter-strand and intra-strand crosslinks between cisplatin and DNA leads to conformational changes of the DNA. To understand the changes caused in DNA conformation due to the adducts formed by cisplatin, the formation of $1,2-\mathrm{GG}$ or $1,3-\mathrm{GTG}$ ${ }_{65}$ intra-strand cross-links and their characterization by Raman spectroscopy has been carried out ${ }^{15}$ and it was found that 1,3 GTG cross linkages induce more distortion in the B-form DNA as compared to the 1,2-GG complex.

${ }_{70}$ The aim of the current study is to evaluate the quantitative predictive capabilities of CRM in the elucidation of the mode of action of chemotherapeutic agents, using cisplatin and A549 adenocarcinoma cells as a model compound and test system respectively. Spectra of the cellular nuclei were 75 taken after a 96 hour exposure period to the agent, and multivariate models of the variation in spectral content with levels of exposure and with degrees of cytotoxicological response were constructed. A feature selection technique was then used to identify regions of the ${ }_{80}$ spectrum that were associated with the biochemical effect of exposure to the agent, and with the subsequent cytotoxicological response of the cells. It is demonstrated 
that the CRM data, in conjunction with multivariate modeling, is capable of identifying spectral signatures of both the biochemical action and physiological response to exposure to the chemotherapeutic agent, and that the 5 measurement may be used in predicting both responses in cancer cells

\section{Materials and methods}

\section{${ }_{10}$ Cell culture}

A549 human lung adenocarcinoma cells were obtained from ATCC (CCL-185). The cells were cultured in DMEM F-12 (Sigma Aldrich, Ireland) medium supplemented with $10 \%$ FBS, $1 \mu \mathrm{g} / \mathrm{ml}$ hydrocortisone (Sigma), $2 \mathrm{mM} \mathrm{L-}$ 15 glutamine (Gibco) and $1 \%$ penicillin- streptomycin (Gibco). Cells were incubated at $37^{\circ} \mathrm{C}$ in $5 \% \mathrm{CO}_{2}$ and routinely subcultured with $1: 1$ ratio of $0.25 \%$ trypsin and $0.1 \%$ EDTA when they reached $70-80 \%$ confluency.

\section{${ }_{20}$ Cytotoxicity assay}

Cisplatin, obtained from Sigma Aldrich, Ireland, was dissolved in $1 \% \mathrm{NaCl}$ (Sigma Aldrich, Ireland) solution $(\mathrm{pH} 7)$ to prepare the stock solution. Working solutions of the drug were prepared in cell culture media. MTT [3-(4,5-

${ }_{25}$ dimethylthiazol-2-yl)-2,5-diphenyl tetrazolium bromide] was obtained from Sigma Aldrich, Ireland. The MTT assay was performed in triplicate according to a method reported previously ${ }^{16,17}$ with a slight modification. MTT is a yellow coloured molecule that is converted to purple formazan by 30 mitochondrial reductases in living cells, and thus measurements of its absorbance are indicative of the level of cellular metabolic activity and the consequent levels of DNA repair activity and cell death after exposure to Cisplatin. A 96-hour exposure period to Cisplatin was ${ }_{35}$ chosen along with a wide range of exposure concentrations as this provided a wide range of measurements of degrees of cytotoxicity with which to challenge the predictive ability of the Raman spectral measurement.

${ }_{40}$ The MTT measurement protocol was as follows. Cells were cultured in 96-well plates (Nunc, Denmark) at a density of $2 \times 10^{3}$ cells per well in DMEM-F12 medium with all the supplements as listed above. After $24 \mathrm{hrs}$ of initial cell attachment, the plates were washed with 100

${ }_{45} \mu \mathrm{l} /$ well phosphate buffered saline (PBS) and were treated with varying concentrations of cisplatin in the range from $0.05 \mu \mathrm{M}-50 \mu \mathrm{M}$ (including a separate unexposed control sample). Following a 96-hour exposure period, the cells were rinsed with PBS and $100 \mu \mathrm{l}$ of fresh medium (without ${ }_{50}$ supplements) were added to each well. A volume of $10 \mu \mathrm{l}$ of MTT $(5 \mathrm{mg} / \mathrm{ml})$ prepared in PBS was then added to each well and the plates were incubated for $3 \mathrm{hrs}^{16}$ at $37^{\circ} \mathrm{C}$ in a $5 \% \mathrm{CO}_{2}$ humidified incubator. After this incubation period, the medium was discarded, the cells were washed with 100 ${ }_{55} \mu \mathrm{l}$ of PBS and $100 \mu \mathrm{l}$ of DMSO were added to each well to extract the dye. The plates were then shaken 240 times per minute for $10 \mathrm{~min}$ and the absorbance was measured at 570 nm using a micro plate reader (Tecan Genios, Grodig, Austria). Six replicate wells were used for each exposure.

60

Sample preparation for Confocal Raman Microspectroscopy For CRM, cell samples were cultured on quartz substrates according to a protocol outlined elsewhere ${ }^{6}$. Briefly, quartz coverslips were coated with a $2 \%$ w/v gelatin-water ${ }_{65}$ solution and maintained at $4{ }^{\circ} \mathrm{C}$ for $6 \mathrm{hrs}$ to allow polymerization of the gelatin to the substrate. Subsequently, $2.5 \times 10^{3}$ A549 cells were attached to the substrates for a 48 hour period, and were exposed to the cisplatin concentrations employed for the cytotoxicity 70 assay for a 96-hour period (together with a non-exposed control sample). After the exposure period, the cells were fixed in $4 \%$ formalin for 10 minutes and were stored in 0.9 $\%$ physiological saline solution at $4{ }^{\circ} \mathrm{C}$ until the Raman analysis was performed. All samples were prepared in 75 triplicate.

\section{DNA extraction}

The cellular DNA was extracted from both a control sample of A549 cells together with a sample of A549 cells 80 exposed to $3 \mu \mathrm{M}$ cisplatin for 96 hours. As determined using the cytotoxicity assay, at this concentration, the viability has reduced to approximately $30 \%$ and thus it represents the $1 / \mathrm{e}$ point of the response. Briefly, cells were trypsinised and centrifuged to form a pellet of cells, and 1 ${ }_{85} \mathrm{ml}$ TRIzol reagent (Invitrogen) per $5-10 \times 10^{6}$ cells was added. The samples were then homogenized and incubated at room temperature for $5 \mathrm{~min}$ to induce cell lysis. For each $\mathrm{ml}$ of TRIzol reagent, $200 \mu \mathrm{l}$ of chloroform was added and samples were centrifuged at $12,000 \times g$ for 5 min at $4{ }^{\circ} \mathrm{C}$. ${ }_{90}$ Following centrifugation, the mixture separated out into a lower red organic phase, a thin interphase and a colourless upper aqueous phase. The DNA was precipitated from the interphase and organic phase with $300 \mu \mathrm{l}$ of $100 \%$ ethanol per $\mathrm{ml}$ of TRIzol reagent. Once precipitated, the DNA was 95 washed twice in a solution of $0.1 \mathrm{M}$ trisodium citrate in $10 \%$ ethanol. The DNA was then dissolved in $\mathrm{dH}_{2} \mathrm{O}$ as water has a significantly weaker Raman signal than common organic solvents. Samples were mixed by inversion, left at room temperature for 2-3 min and then 100 centrifuged at $2,000 \times g$ for $5 \mathrm{~min}$ at $4{ }^{\circ} \mathrm{C}$. The DNA pellet was recovered and maintained at $-20{ }^{\circ} \mathrm{C}$ until analysis. To ensure the purity of the DNA, the absorbance of the sample was recorded on a UV-Vis spectrophotometer according to the manufacturer's protocol.

105

\section{Spectral Acquisition}

CRM was conducted with a Horiba Jobin-Yvon, LabRam HR800 instrument using a $785 \mathrm{~nm}$ laser as source. The 110 laser power was approximately $70 \mathrm{~mW}$ at the sample. Spectra were taken in the range from $600 \mathrm{~cm}^{-1}$ to $1800 \mathrm{~cm}$ ${ }^{1}$ with a confocal hole diameter of $100 \mu \mathrm{m}$. A $\times 100$ water immersion objective was used to focus the laser on the sample, immersed in $0.9 \%$ saline, yielding a spot size of ${ }_{115} \sim 1 \mu \mathrm{m}$. Multiple spectra were recorded from the nuclear 
portion of a total of 60 cells at each exposure level. Subsequently the spectra were filtered with a SavitskyGolay filter (order 5, 13 point window), and the quartz signal background was subtracted using algorithms ${ }_{5}$ developed in-house. Prior to analysis the spectra were also vector normalized. For the acquisition of the spectra from the extracted DNA, the DNA solution was drop cast onto quartz substrates. The Raman spectrum of pure cis-platin was measured in the raw powder form.

\section{Data analysis}

All spectral analysis was performed in the Matlab 7.2 (The Mathworks Inc.) environment employing the PLS Toolbox ${ }_{15}$ 5.0.3 (Eigenvector Research, Wenatchee, WA) and algorithms developed in-house. Outlying spectra were removed using Grubb's filtering ${ }^{18}$. All spectra, including calibration and substrate backgrounds, were vector normalized. The substrate spectra were subtracted from

${ }_{20}$ each spectrum and a fifth order polynomial was fitted to the spectra to remove any residual spectral baseline. Multivariate regression models were constructed using Partial Least Squares Regression (PLSR) ${ }^{19}$ and PLS Jackknifing was employed as a multivariate feature selection ${ }_{25}$ technique ${ }^{5,20,21}$. The PLSR algorithm seeks to develop a model that relates the spectral data $(X$-matrix) to a series of targets ( $Y$-matrix, e.g. concentration of reaction product or analyte) according to the equation $Y=X B+E$, where $B$ is a matrix of regression coefficients and $E$ is the regression 30 residual. The Y-matrix here consisted of values of the concentration of cisplatin to which the cell was exposed, or the measured level of cell viability from the MTT assay. The PLS Jack-knifing method developed by Westad and Martens ${ }^{21}$ was then used to determine the spectral features 35 that were statistically significant at a particular level of confidence using t-testing of the regression coefficients, $B$. The Raman band assignments used in the interpretation of the spectral features were taken from the literature ${ }^{6,22-25}$.

\section{${ }_{40}$ Results and Discussion}

Cytotoxicity assay

The MTT assay is a measure of the mitochondrial metabolic activity and in the current study is used initially ${ }_{45}$ as a standard against which to map the response as measured by CRM. Maximum cytotoxicity was observed after $96 \mathrm{hrs}$ exposure and thus this time period was employed for all measurements. The cytotoxicity induced in A549 cells due to the exposure to cisplatin for 96hrs, as ${ }_{50}$ determined by the MTT assay, is shown in Figure 1, where the level of viability in each sample was normalised to that in the control sample. Due to the action of the drug, the mitochondrial activity decreases monotonically which in turn leads to a decrease in cell viability. The Inhibitory ${ }_{55}$ Concentration $\left(\mathrm{IC}_{50}\right)$ value was derived from the data by a fit of $\mathrm{f}(\mathrm{x})=\min +(\max -\min ) /\left(1+\left(\mathrm{x} / \mathrm{IC}_{50}\right)^{\wedge} \mathrm{n}\right)$ and found to be $1.2 \pm 0.2 \mu \mathrm{M}$, which is consistent with the literature. For A549 cells exposed to test drug concentration (TDC) for
$72 \mathrm{hrs}, \mathrm{IC}_{50}$ values of $3.59 \mu \mathrm{M}$ and $2.2 \mu \mathrm{M}$ are reported ${ }_{60}$ elsewhere with MTT and ATP assays respectively ${ }^{26}$. Also, Cordes et al. have determined an $\mathrm{IC}_{50}$ value of $2.0 \mu \mathrm{M}$ for cisplatin $(0.1-50 \mu \mathrm{M})$ exposed A549 cells using the colony formation assay ${ }^{27}$.

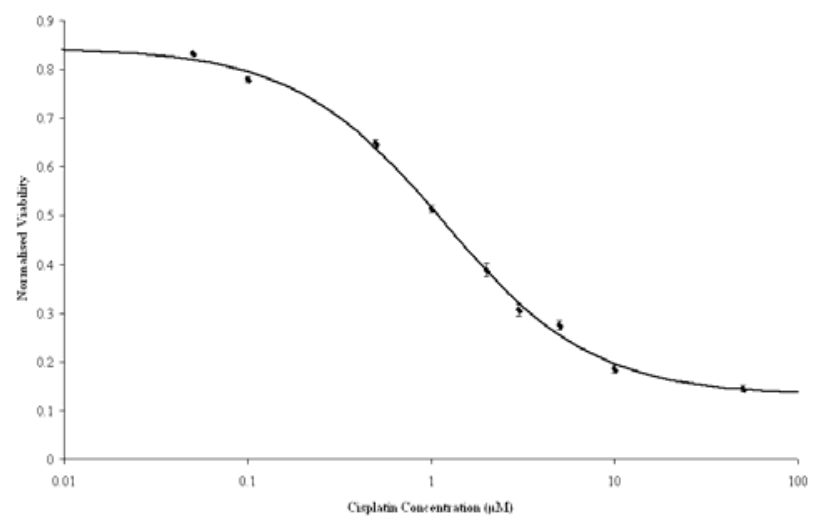

65 Figure 1. A549 cell viability (measured by MTT absorption) at 96 hours after exposure to Cisplatin. Error bars denote the standard error on the mean at each concentration.

\section{Raman Spectrum of Cisplatin}

70

The Raman spectrum of pure cisplatin is shown in Figure 2. The most prominent features lie in the region between $100-550 \mathrm{~cm}^{-1} 28$, which does not fall within the $600-1800$ $\mathrm{cm}^{-1}$ spectral window of the current measurements and 75 therefore they do not contribute to the cellular spectrum.

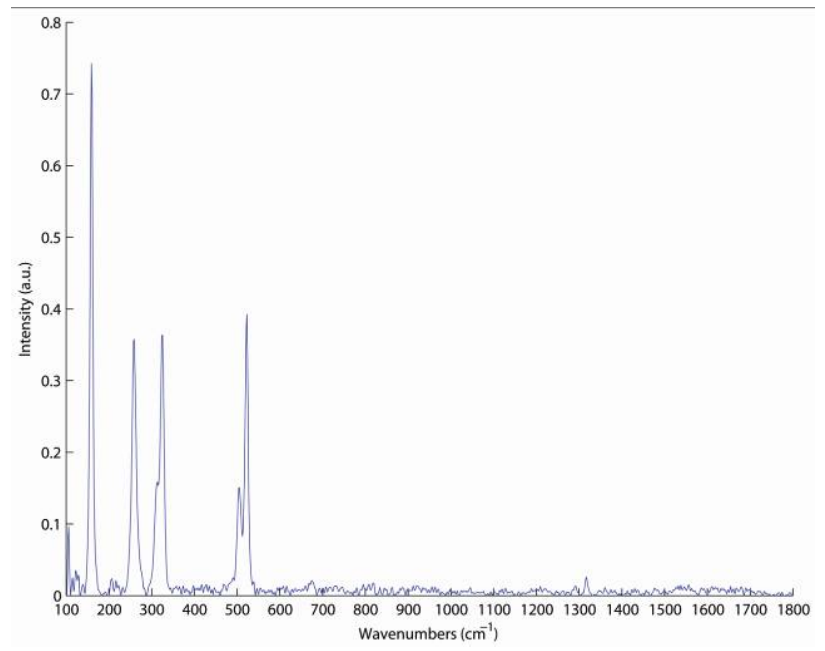

Figure 2. Raman spectrum of cisplatin powder

\section{${ }_{80}$ Nuclear spectral features}

Figure 3A shows the mean control spectra of the nucleus of A549 cells. The Raman bands which are important and in which changes due to the action of cisplatin may be ${ }_{85}$ expected are labelled. The Raman bands at $669 \mathrm{~cm}^{-1}$ and $1375 \mathrm{~cm}^{-1}$ can be assigned to thymine and at $1336 \mathrm{~cm}^{-1}$ to guanine. Two bands at $807 \mathrm{~cm}^{-1}$ and $833 \mathrm{~cm}^{-1}$ are assigned, respectively, to the O-P-O stretching of the DNA-A and -B forms and the peak at $1095 \mathrm{~cm}^{-1}$ is assigned to the O-P-O ${ }_{90}$ stretching of the DNA backbone in general. Other 

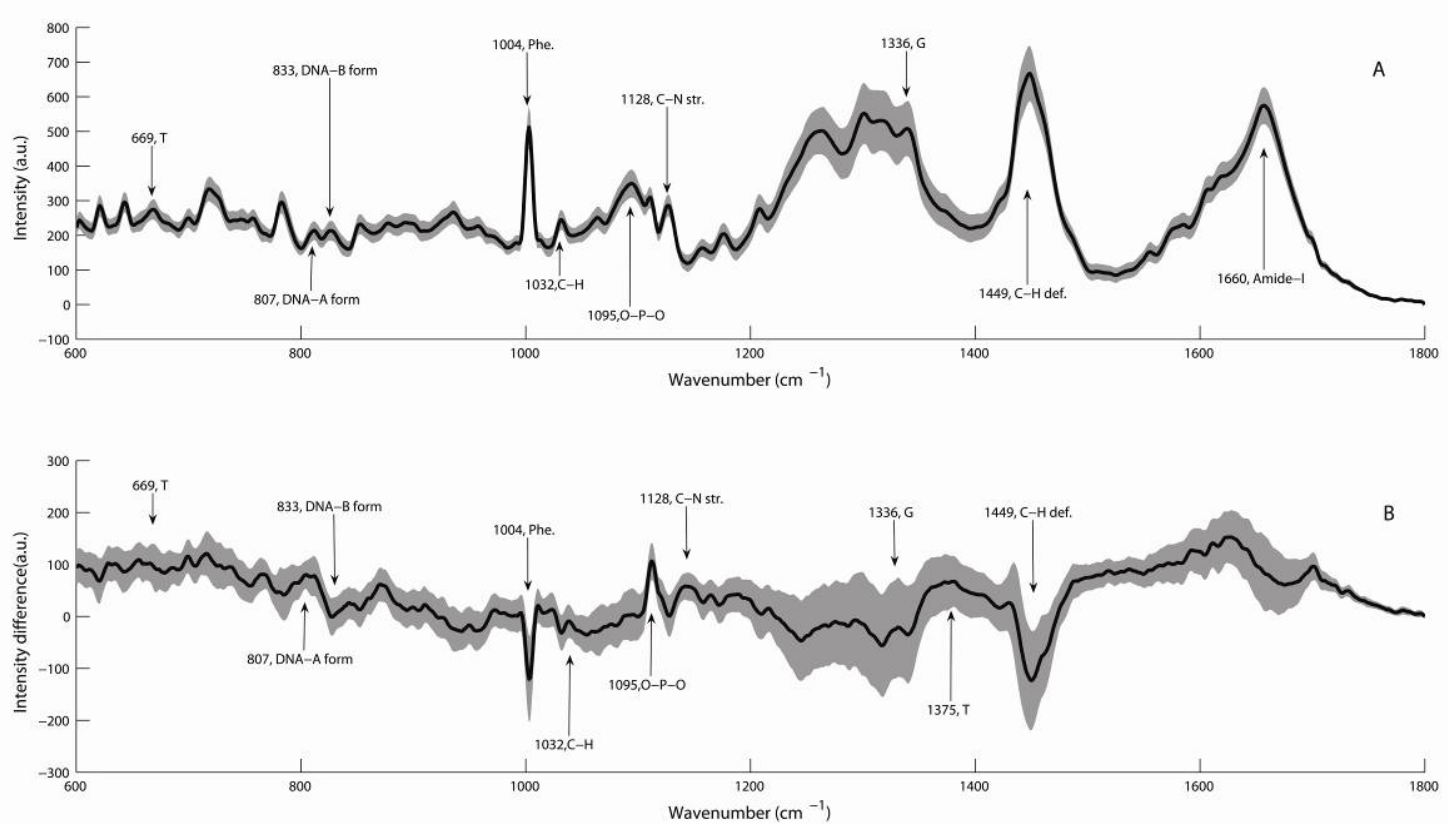

Figure 3. Mean spectrum of the nucleus of control sample (A) and the difference spectrum (B) between the mean of the control and the sample exposed to $3 \mu \mathrm{M}$ cisplatin. The shaded area around each trace defines the standard error on the mean.
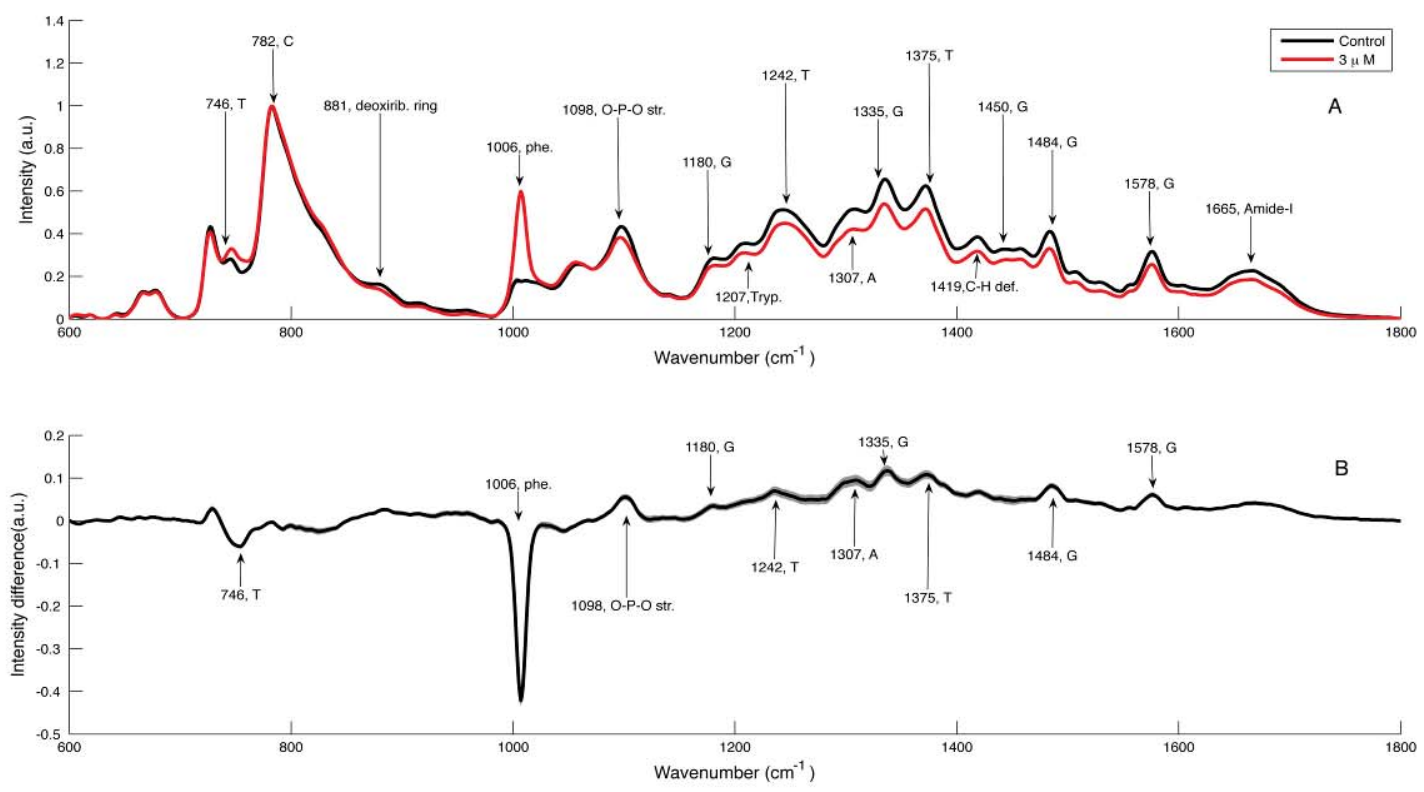

Figure 4 Raman spectra of DNA extracted from A549 cells exposed to $3 \mu \mathrm{M}$ cisplatin for 96 hrs; Mean control and exposed spectra (A) and difference spectrum (B). The extent of each trace defines the mean spectrum plus the standard error on the mean (which are very small and thus invisible in most instances). 
prominent Raman bands derive from $\mathrm{C}-\mathrm{H}$ deformation of lipids $\left(1449 \mathrm{~cm}^{-1}\right)$ and the amide-I band for proteins (1660 $\left.\mathrm{cm}^{-1}\right)$. Lipid peaks $\left(1480-1420 \mathrm{~cm}^{-1}\right)$ in the nuclear spectra may originate from contributions of the surrounding 5 cytoplasm $^{8,23}$.

Figure 3B shows the mean difference spectrum of the nucleus of A549 cells exposed to $3 \mu \mathrm{M}$ cisplatin versus its control. The major changes observed are labelled. The 10 bands for DNA bases including thymine (at $669 \mathrm{~cm}^{-1}$ and $\left.1375 \mathrm{~cm}^{-1}\right)$ and guanine $\left(1336 \mathrm{~cm}^{-1}\right)$ are significantly changed due to the binding of the cisplatin. As the cisplatin can form two types of intrastrand crosslinks, 1,2 GG and 1,3 GTG, the Raman spectral changes (i.e. to the Raman 15 bands of the Guanine $(\mathrm{G})$ and thymine $(\mathrm{T})$ ) may indicate the presence of both types of crosslinkages due to the action of the cisplatin. ${ }^{15}$ The bands associated with the DNA-A and -B form are seen to change in intensity, the B-form band at $833 \mathrm{~cm}^{-1}$ to a much greater degree. This could be indicative 20 of the induction of conformational changes in the B-form of DNA due to the formation of intra-strand crosslinkages of the cisplatin with guanine and adenine and binding with thymine. This represents a Raman marker of the binding of cisplatin with the DNA bases. The changes observed in the ${ }_{25}$ bands for the O-P-O backbone of DNA, at $1095 \mathrm{~cm}^{-1}$, can be a marker for the changes in the electrostatic environment of the phosphate group ${ }^{29,30}$.

Changes in the bands at $1032 \mathrm{~cm}^{-1}$ (C-H stretching), 1128 (C-N stretching) and $1660 \mathrm{~cm}^{-1}$ (amide-I), are related to 30 protein structure. This may be due to the fact that after the conformational changes caused in the DNA by cisplatin binding, high mobility group proteins bind to the site where the cisplatin molecule has bound to the DNA and prevent repair by nuclease enzyme excision ${ }^{31}$.

35

\section{Spectral features of extracted nuclear DNA}

In order to further confirm the Raman markers for the known mechanism of action of the cisplatin, the spectra 40 recorded of the DNA extracted from the control and exposed (3 $\mu \mathrm{M}$ for comparison to the spectroscopic analyses of the cells) A549 cells were analyzed. The mean control and the difference spectra of the extracted DNA are shown in Figure 4A and Figure 4B respectively. The ${ }_{45}$ DNA extracted from the unexposed control and the cisplatin exposed samples were measured under identical conditions and thus it is concluded that the spectral differences are due to the cis-platin exposure alone, rather than the laser.

${ }_{50}$ Changes in the Raman bands of the DNA bases are observed, as expected, including guanine $\left(1180 \mathrm{~cm}^{-1}, 1335\right.$ $\left.\mathrm{cm}^{-1}, 1450 \mathrm{~cm}^{-1}, 1484 \mathrm{~cm}^{-1}, 1578 \mathrm{~cm}^{-1}\right)$, thymine $\left(746 \mathrm{~cm}^{-1}\right.$, $1242,1375)$ and adenine $\left(1307 \mathrm{~cm}^{-1}\right)$. Changes in the bands related to the DNA backbone, deoxyribose ring 55 breathing $\left(881 \mathrm{~cm}^{-1}\right)$ and phosphodioxy stretching vibrations $\left(1098 \mathrm{~cm}^{-1}\right)$ are also observed, indicative of the conformational changes caused in the DNA by the cisplatin action.
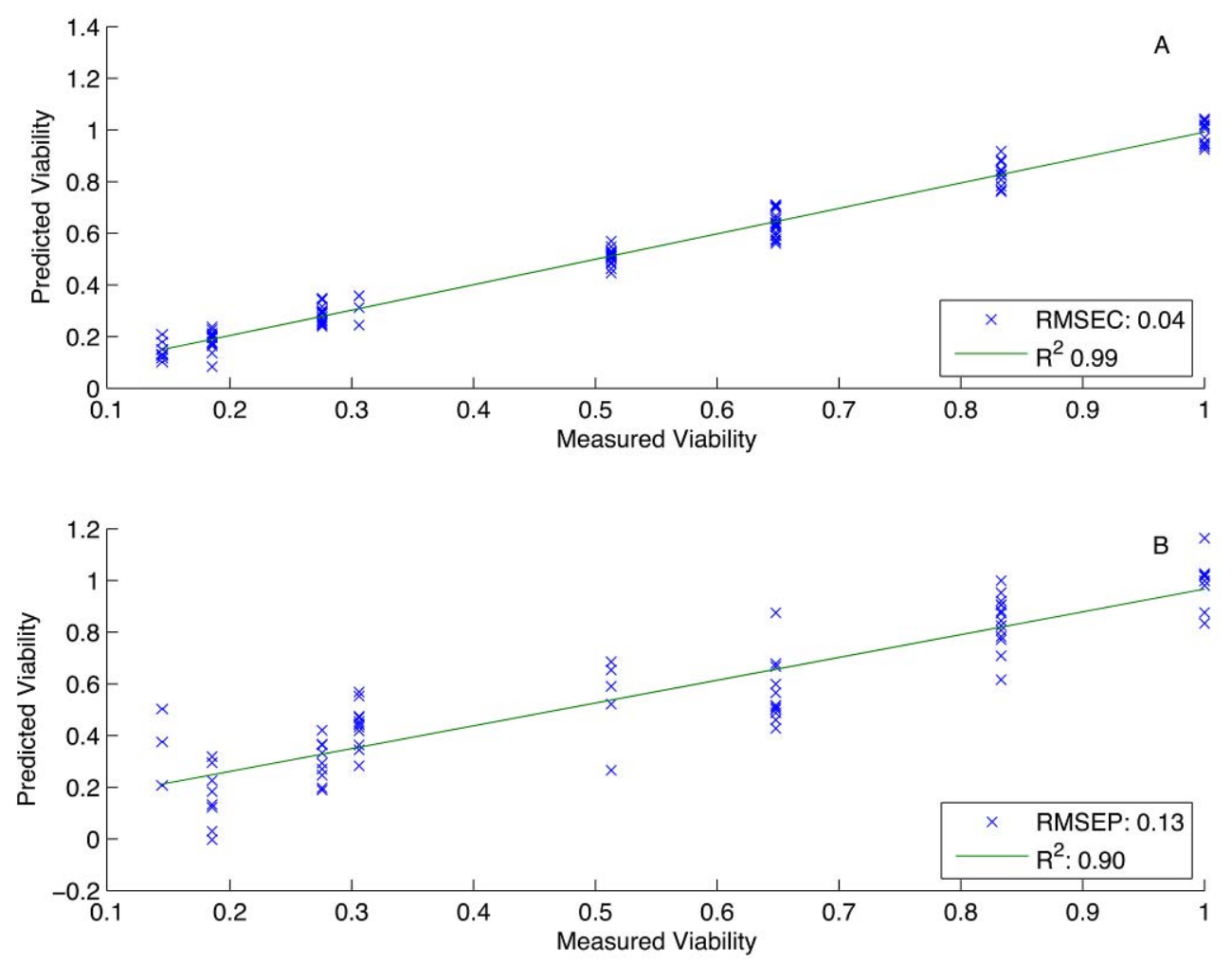

Figure 5. Calibration (A) and test set performance (B) in prediction with PLSR of the cell viability using Raman spectra of the nucleus of A549 cells. Root mean squared errors of calibration (RMSEC) and prediction (RMSEP) are in units of cell viability, which themselves are normalized to the level in the control. 


\section{Prediction of exposure level and cellular viability with PLSR}

CRM can clearly fingerprint the effects of the interaction of the chemotherapeutic agent with DNA, and identify that ${ }_{5}$ fingerprint within the cellular spectra of exposed cells. PLSR models of A549 nuclear spectra versus concentration and reference viability measurements from the MTT assay were constructed to determine the ability of the spectral data to predict the level of exposure to ${ }_{10}$ cisplatin and the associated level of physiological effect from Raman spectra. All spectra were compiled into a matrix, and were randomly sorted. A total of $60 \%$ of the spectra were used to train the PLSR regression model and of the total was retained as an independent test set to assess

15 the performance of the model in predicting the level of exposure, and the cellular viability, with unseen data. Leave-one out cross validation with the calibration set was used to determine the optimal model complexity for use in testing $^{32}$. This process was performed on fifty separate 20 occasions, with randomization of the data matrix and splitting of the data on each occasion to prevent data bias ${ }^{19}$. An example of the results of prediction of levels of cellular viability is shown in Figure 5, where the values of the root mean square error of calibration (RMSEC) and the root 25 mean square error of prediction (RMSEP) denote the prediction uncertainty. The mean values of the RMSEC and RMSEP for the PLSR for prediction of the level of exposure to cisplatin were found to be $1.67 \mu \mathrm{M}(0.45)$ and $3.41 \mu \mathrm{M}(0.41)$ respectively, where the figures in brackets

30 denote the standard deviations of these estimates. The associated values of RMSEC and RMSEP for PLSR against normalized cellular viability were $0.05(0.008)$ and 0.11 (0.011) respectively. The RMSEP for prediction of cisplatin concentration is therefore $6.8 \%$ over the full scale ${ }_{35}$ range $(0$ to $50 \mu \mathrm{M})$, and $11 \%$ over the full scale range of viability (from 0 to 1 ). The proportionally higher observed errors of prediction of cell viability may be due to the development of cellular resistance to cisplatin over the exposure period in the low dose groups ${ }^{33,34}$, which 40 contributes to a non-linearity in the variation in viability with concentration that is difficult for the PLSR algorithm to model.

\section{Feature Selection by PLS Jack-knifing}

45

The spectral changes observed in Figure 2 are multivariate and may have complex exposure dependence. It has been demonstrated that they include the fingerprint of the interaction of the cisplatin with the nuclear DNA, but also ${ }_{50}$ evident are a multitude of other changes associated with exposure and changes in cellular physiology. In an effort to identify the most important spectral features, feature selection was performed using a Partial Least Squares Jack knifing analysis described earlier. The regression co${ }_{55}$ efficients were obtained by PLS-Jack knifing for separate regressions against cisplatin concentrations and against cell viability with the nuclear spectral data. To elucidate spectral changes that are most statistically significant with respect to regression against either endpoint, a t-test ${ }_{60}(\mathrm{p}<0.001)$ was applied on the PLS-Jack knifing results, where the spectral features identified by this process are highlighted by vertical bands in Figure 6.
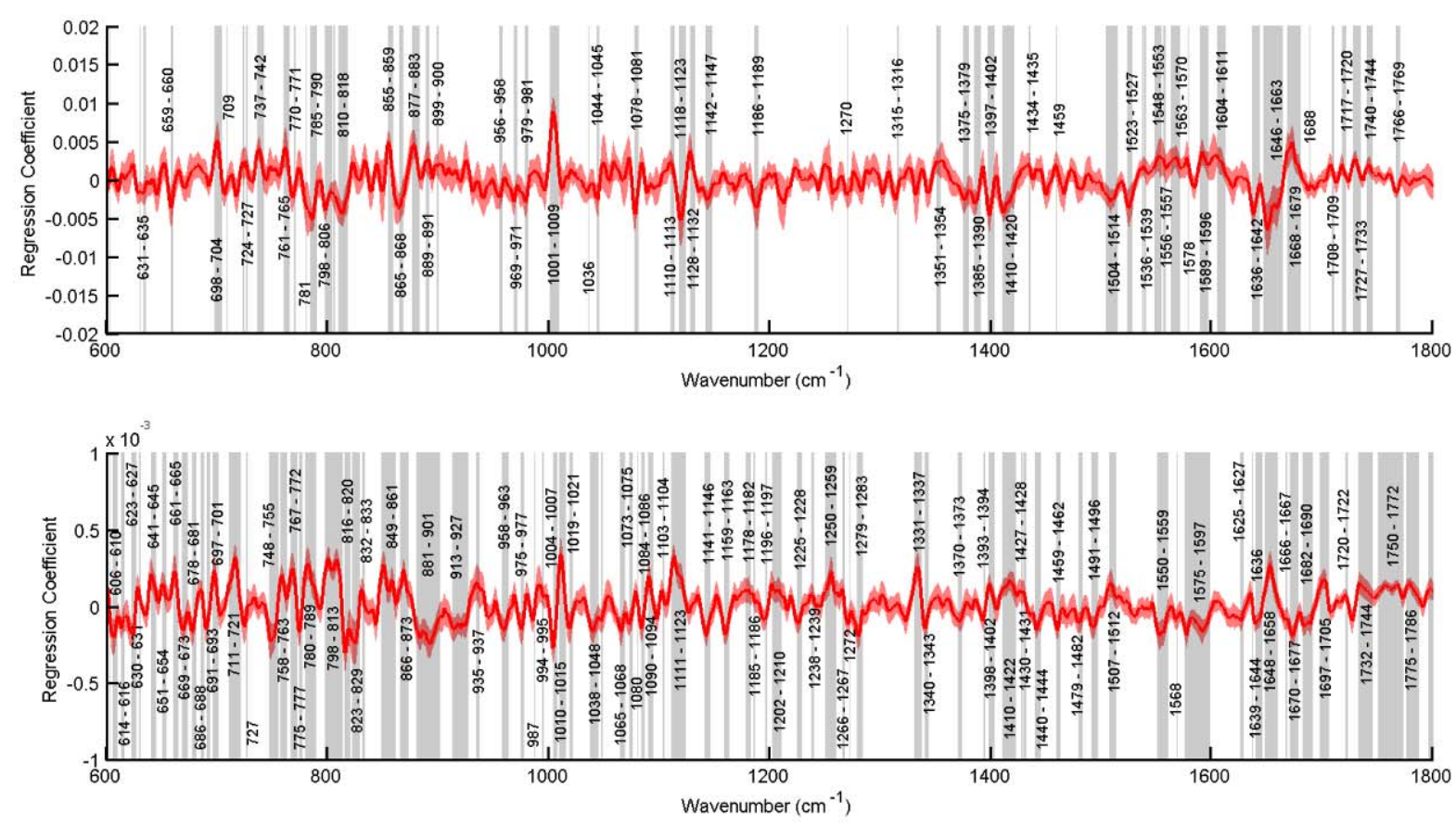

Figure 6. Feature selection in PLSR of Raman spectra of the A549 nucleus against (A) cisplatin concentrations and (B) against cellular viability. The shaded areas denote statistically significant features selected using PLS Jack-knifing with a t-test $(p<0.001)$ of regression coefficients (shown in red with associated standard error). 
The PLS regression of the nuclear data against cisplatin concentration (Figure 5A), identifies many features but for the purpose of this discussion only the changes which are related to the known action of cisplatin are highlighted. ${ }_{5}$ Features identified include the thymine $\left(737-742 \mathrm{~cm}^{-1}\right.$, $\left.1589-1595 \mathrm{~cm}^{-1}\right)$, guanine $\left(1548-1553 \mathrm{~cm}^{-1}\right)$ and adenine $\left(1578 \mathrm{~cm}^{-1}, 1604-1611 \mathrm{~cm}^{-1}\right)$ bands. The regression coefficients of guanine and thymine are stronger than that of adenine indicating that cisplatin binds preferably with 10 guanine as compared to adenine ${ }^{35}$. Another interesting observation is that the bands at $\left(877-883 \mathrm{~cm}^{-1}\right)$ and at $(899-$ $900 \mathrm{~cm}^{-1}$ ) both assigned to deoxiribose ring breathing, are significantly changed, which lead to a change in the conformation of B-form DNA ${ }^{36-38}$. Changes in the Raman 15 bands of the proteins are also highlighted, as indicated by the regression co-efficients which can be assigned to tryptophan ring breathing $\left(761-765 \mathrm{~cm}^{-1}\right),\left(889-891 \mathrm{~cm}^{-1}\right)$, C-N stretching (1128-1132 $\left.\mathrm{cm}^{-1}\right), \mathrm{C}-\mathrm{H}$ deformation (1315$\left.1316 \mathrm{~cm}^{-1}, 1351-1354 \mathrm{~cm}^{-1}\right)$, amide-I $\left(1668-1679 \mathrm{~cm}^{-1}\right)$. ${ }_{20}$ These changes may indicate some structural changes in the nuclear proteins.

The regression against cell viability (Figure 5B), shows the features which are changed significantly due to the change ${ }_{25}$ in cell physiology. These include the conformational changes of the DNA B-form (832-833 $\left.\mathrm{cm}^{-1}\right)$ and DNA Aform $\left(798-813 \mathrm{~cm}^{-1}\right)$. These changes in the Raman bands of the DNA can be taken as markers for the conformational changes in the DNA caused by cisplatin binding to the ${ }_{30}$ guanine and thymine DNA bases ${ }^{15}$ and also confirm the observations from the mean difference spectra. Changes related to protein secondary and tertiary structures are indicated by the selection of amide-III random coil (1225$1228 \mathrm{~cm}^{-1}$ ), amide-III $\beta$-sheet (1250-1259), amide-III alpha 35 helix, tryptophan ring breathing (711-721 $\mathrm{cm}^{-1}, 758-763$ $\left.\mathrm{cm}^{-1}, 767-772 \mathrm{~cm}^{-1}\right)$ and phenyl ring stretching modes $\left(1202-1210 \mathrm{~cm}^{-1}\right)$ together with the C-C skeletal vibrations (935-937 $\left.\mathrm{cm}^{-1}, 1159-1163 \mathrm{~cm}^{-1}\right), \mathrm{C}-\mathrm{N}$ stretching vibrations (1065-1068, 1073-1075) and C-H bending (1178-1182 $\mathrm{cm}^{-}$ $\left.{ }_{40}{ }^{1}\right)\left(1185-1186 \mathrm{~cm}^{-1}\right)$. These features suggest changes in the Raman bands of proteins and are indicative of structural alterations associated with protein activation and denaturation during cellular apoptosis and nucleic acid repair responses.

45

Comparing the regression co-efficients obtained via spectral regression against cisplatin concentration (which highlight the primary biochemical effect of the action of the agent) with those obtained via regression against cell 50 viability (which highlight biochemical markers of the change in the viability of the cell), very different spectral features are selected as being statistically significant and thus allow the differentiation of the chemotherapeutic response. The spectral features of thymine $\left(737-742 \mathrm{~cm}^{-1}\right.$, $\left.{ }_{55} 1589-1595 \mathrm{~cm}^{-1}\right)$, guanine $\left(1548-1553 \mathrm{~cm}^{-1}\right)$ and adenine $\left(1578 \mathrm{~cm}^{-1}, 1604-1611 \mathrm{~cm}^{-1}\right)$ feature prominently as a result of regression against the concentration of the chemotherapeutic agent and are attributable to direct binding of the cisplatin molecule with these DNA bases. In ${ }_{60}$ addition, changes related to proteins feature in the regression against the concentration of the chemotherapeutic agent are significantly different than those changes of protein associated bands which appear as a result of regression against the cellular viability. The ${ }_{65}$ changes in the features of the proteins due to the chemical effect are attributable to structural changes in nuclear histone proteins due to cisplatin interactions with the cellular DNA. These features are not selected as being statistically significant by the analysis for regression 70 against the viability endpoint, suggesting that they are markers of the biochemical interaction between cisplatin and DNA. Contrastingly, the conformational changes to the DNA A-form (798-813 $\left.\mathrm{cm}^{-1}\right)$ and DNA B-form (832$833 \mathrm{~cm}^{-1}$ ), among the changes associated with the protein 75 features, especially the amide-III random coil (1225-1228 $\mathrm{cm}^{-1}$ ), amide-III $\beta$-sheet (1250-1259), amide-III alpha helix, among others, are selected as being statistically significant in the regression against cellular viability suggesting that they are markers of this physiological ${ }_{80}$ endpoint in the chemotherapeutic response. Overall, Figure 5 demonstrates that the Raman spectrum of the cell may be resolved into distinct groups of statistically significant spectral markers for distinct types of effect.

${ }_{85}$ "The study demonstrates the potential of commercially available benchtop CRM for the examination and prediction of chemotherapeutic responses. In general, for subcellular resolution, Raman spectroscopy is chosen over infrared spectroscopy due to the intrinsically higher spatial ${ }_{90}$ resolution. Furthermore, the relative insensitivity to water renders live cell imaging of real time exposures a possibility $^{39}$. Nonlinear optical imaging techniques ${ }^{40}$ promise even higher spatial resolution in the future, but at present such short pulse systems cannot be considered ${ }_{95}$ benchtop techniques."

Cisplatin, a DNA major groove binder ${ }^{41}$, was chosen as a model as its mechanism of action is well characterised. To fully validate the technique, the study should be extended 100 to other chemotherapeutic agents of known interaction mechanisms, such as tallimustine, a known DNA minor groove binder, and ethidium bromide, a known DNA intercalator. In this way the spectroscopic signatures of their interaction can be established and subsequently can ${ }_{05}$ act as a database against which novel chemotherapeutic agents can be evaluated. Ultimately, the techniques should be validated in tumour tissue.

\section{$\$$ Acknowledgements} 110

The authors acknowledge funding through the Technology Sector Research (Strand III) programme of the Irish Higher Education Authority and the Irish HEA Programme for Research in Third Level Institutions, Cycle 4 National ${ }_{15}$ Biophotonics and Imaging Platform for Ireland (NBIPI). 


\section{References}

1. F. M. Lyng, E. O. Faolain, J. Conroy, A. D. Meade, P. Knief, B. Duffy, M. B. Hunter, J. M. Byrne, P. Kelehan and H. J. Byme, Experimental and Molecular Pathology, 2007, 82, 121-129.

2. J. Chan, S. Fore, S. Wachsman-Hogiu and T. Huser, Laser \& Photonics Reviews, 2008, 2, 325-349.

3. T. Huser, C. A. Orme, C. W. Hollars, M. H. Corzett and R. Balhorn, Journal of Biophotonics, 2009, 2, 322-332.

10 4. P. Knief, C. Clarke, E. Herzog, M. Davoren, F. M. Lyng, A. D. Meade and H. J. Byrne, 2009, pp. 1182-1191.

5. A. D. Meade, H. J. Byrne and F. M. Lyng, Mutation ResearchReviews in Mutation Research, 2010, 704, 108-114.

6. A. D. Meade, F. M. Lyng, P. Knief and H. J. Byrne, Anal Bioanal Chem, 2007, 387, 1717-1728.

7. C. A. Owen, J. Selvakumaran, I. Notingher, G. Jell, L. L. Hench and M. M. Stevens, Journal of Cellular Biochemistry, 2006, 99, 178-186.

8. F. Draux, P. Jeannesson, A. Beljebbar, A. Tfayli, N. Fourre, M.

20 Manfait, J. Sule-Suso and G. D. Sockalingum, Analyst, 2009, 134, 542-548.

9. J. Ling, S. D. Weitman, M. A. Miller, R. V. Moore and A. C. Bovik, Applied optics, 2002, 41, 6006-6017.

10. J. Y. Ling, Q. Z. Yang, S. S. Luo, Y. Li and C. K. Zhang, Chinese $25 \quad$ Chemical Letters, 2005, 16, 71-74.

11. I. Notingher, C. Green, C. Dyer, E. Perkins, N. Hopkins, C. Lindsay and L. L. Hench, Journal of the Royal Society Interface, 2004, 1, 79-90.

12. S. Verrier, I. Notingher, J. M. Polak and L. L. Hench, 2004, pp. $157-$ $30 \quad 162$.

13. Y. Yang, J. Sule-Suso, G. D. Sockalingum, G. Kegelaer, M. Manfait and A. J. El Haj, Biopolymers, 2005, 78, 311-317.

14. B. Kosmider, I. Wojcik, R. Osiecka, J. Bartkowiak, E. Zyner, J. Ochocki and P. Liberski, Investigational New Drugs, 2005, 23, 35 287-297.

15. O. Vrana, V. Masek, V. Drazan and V. Brabec, Journal of Structural Biology, 2007, 159, 1-8.

16. T. Mosmann, Journal of Immunological Methods, 1983, 65, 55-63.

17. S. A. Park, H. J. Park, B. I. Lee, Y. H. Ahn, S. U. Kim and K. S. $40 \quad$ Choi, Molecular Brain Research, 2001, 93, 18-26.

18. F. E. Grubbs, Technometrics, 1969, 11, 1-\&.

19. K. Varmuza and P. Filzmoser, Introduction to Multivariate Statistical Analysis in Chemometrics, CRC Press, Taylor and Francis Group, Boca Raton, FL, 2009.

45 20. H. Martens and M. Martens, 2000, pp. 5-16.

21. F. Westad and H. Martens, Journal of near Infrared Spectroscopy, 2000, 8, 117-124.

22. J. De Gelder, K. De Gussem, P. Vandenabeele and L. Moens, Journal of Raman Spectroscopy, 2007, 38, 1133-1147.

50 23. P. R. T. Jess, V. Garces-Chavez, D. Smith, M. Mazilu, L. Paterson, A. Riches, C. S. Herrington, W. Sibbett and K. Dholakia, Optics Express, 2006, 14, 5779-5791.

24. I. Notingher, Sensors, 2007, 7, 1343-1358.

25. I. Notingher, S. Verrier, S. Haque, J. M. Polak and L. L. Hench, 55 Biopolymers, 2003, 72, 230-240.
26. E. Ulukaya, F. Ozdikicioglu, A. Y. Oral and M. Demirci, Toxicology in Vitro, 2008, 22, 232-239.

27. N. Cordes, C. Beinke, L. Plasswilm and D. van Beuningen, Strahlentherapie Und Onkologie, 2004, 180, 157-164.

60 28. D. Michalska and R. Wysokinski, Chemical Physics Letters, 2005, 403, 211-217.

29. K. L. Aubrey, S. R. Casjens and G. J. Thomas, Biochemistry, 1992, 31, 11835-11842.

30. J. Stangret and R. Savoie, Canadian Journal of Chemistry-Revue 65 Canadienne De Chimie, 1992, 70, 2875-2883.

31. J. C. Huang, D. B. Zamble, J. T. Reardon, S. J. Lippard and A. Sancar, Proceedings of the National Academy of Sciences of the United States of America, 1994, 91, 10394-10398.

32. A. D. Meade, C. Clarke, H. J. Byrne and F. M. Lyng, Radiat Res, 2010, 173, 225-237.

33. C. M. Krishna, G. Kegelaer, I. Adt, S. Rubin, V. B. Kartha, M. Manfait and G. D. Sockalingum, Biopolymers, 2006, 82, 462 470.

34. J. M. Le Gal, H. Morjani and M. Manfait, Cancer Res, 1993, 53, 75 3681-3686.

35. M. H. Baik, R. A. Friesner and S. J. Lippard, Journal of the American Chemical Society, 2003, 125, 14082-14092.

36. S. U. Dunham, S. U. Dunham, C. J. Turner and S. J. Lippard, Journal of the American Chemical Society, 1998, 120, 5395-5406.

80 37. A. Gelasco and S. J. Lippard, Biochemistry, 1998, 37, 9230-9239.

38. P. M. Takahara, A. C. Rosenzweig, C. A. Frederick and S. J. Lippard, Nature, 1995, 377, 649-652.

39. F. Bonnier, A.D. Meade, S. Merzha, P. Knief, K. Bhattacharya, F.M. Lyng and H.J. Byrne, Analyst, 2010, 135, 1697-1703

${ }_{85} 40$ Y. Fu, H. Wang, R. Shi and J.-X. Cheng, Biophysical Journal, 2007, 92, 3251-3259

41. G. Colella, S. Marchini, M. D. D'Incalci, R. Brown and M. Broggini, Br. J. Cancer, 1999, 80, 338-343. 